\title{
Considerations regarding the dominance of Cylindrospermopsis raciborskii under low light availability in a low phosphorus lake
}

\author{
Denise Tonetta $^{1 \star}$, Mariana Coutinho Hennemann ${ }^{1}$, Débora Monteiro Brentano ${ }^{1,2}$ and Mauricio Mello Petrucio
}

Received: February 14, 2015. Accepted: May 4, 2015

\begin{abstract}
Although many studies have shown that the dispersion, increased abundance and dominance of cyanobacteria can be attributed to nutrient enrichment, we discuss features contributing to the dominance of Cylindrospermopsis raciborskii in a shallow, polymictic, subtropical coastal lake with low phosphorus and light limitation (Peri Lake). The presence and dominance of C. raciborskii in an environment with such characteristics emphasizes the idea that nutrients alone do not explain the high density of this cyanobacterium. Other features should be considered in explaining this species dominance, such as phosphorus storage and physiological flexibility, which seem to be key features to high densities in low phosphorus systems.
\end{abstract}

Keywords: Cyanobacteria, cyanotoxins, freshwater, nutrients, Peri Lake, phytoplankton, plasticity, subtropical

In recent years, many studies have shown that the dispersion and increased presence and dominance of Cyanobacteria in lakes can be attributed to nutrient enrichment, especially phosphorus in coastal areas (e.g. Padisák 1997; Heisler et al. 2008; Pearl \& Huisman 2008; Carey et al. 2012; Dolman et al. 2012; Soares et al. 2013). Concomitantly, improvements have been done in order to understand why Cylindrospermopsis raciborskii (Woloszynska) Seenayya \& Subba-Raju has been so successful worldwide (Bonilla et al. 2011; Piccini et al. 2011). In the present short communication, we attempt to contribute to a better understanding and to the discussion about the features contributing to C. raciborskii dominance, especially in a low phosphorus $(\mathrm{P})$ context in southern Brazil.

Peri Lake is a freshwater coastal lake within a conservation area of Subtropical Atlantic Rain Forest located in Santa Catarina Island, which is used as drinking-water supply. The lake has a surface area of $5.07 \mathrm{~km}^{2}$, maximum depth of $11.0 \mathrm{~m}$, and showed spatial homogeneity, both horizontally and vertically, concerning chlorophyll-a and nutrients (Hennemann \& Petrucio 2011). The lake has been considered polymictic and light limited, according to Tonetta et al. (2013). However, recent findings from high-frequency measurements taken from the deepest part of the lake have shown that some short stratifications and de-stratifications occur on a daily basis, that the mixing zone is highly variable, and the euphotic zone is on average $4.0 \mathrm{~m}$ (D. Tonetta, unpubl. res.). Despite low concentration of dissolved inorganic nutrients (mean soluble reactive phosphorus: $2.5 \mu \mathrm{g} . \mathrm{L}^{-1}$; ammonium: $15.0 \mu \mathrm{g} . \mathrm{L}^{-1}$; nitrate: $6.1 \mu \mathrm{g} . \mathrm{L}^{-1}$; and nitrite: $\left.0.4 \mu \mathrm{g} . \mathrm{L}^{-1}\right)$, total nutrients indicate a mesotrophic condition (mean Total Nitrogen: $746 \mu \mathrm{g} . \mathrm{L}^{-1}$; mean Total Phosphorus: $\left.14.8 \mu \mathrm{g} . \mathrm{L}^{-1}\right)$ and a potential $\mathrm{P}$ limitation to phytoplankton growth (Reynolds 2006). A previous study in the lake showed that traditional trophic state indices do not represent conditions in Peri Lake appropriately (Hennemann \& Petrucio 2011). According to the authors, the indices developed for temperate lakes indicate a mesotrophic condition concerning total P concentration, while indices adapted for warmer water bodies considered the lake oligotrophic. Additionally, the classification considering Secchi disk depth (water transparency) and chlorophyll-a concentration also differed significantly (from mesotrophic to hypertrophic), according to the index used (see Hennemann \& Petrucio 2011 for an extended discussion about application of trophic state indices in the lake). The relative high chlorophyll-a concentration $\left(17.7 \mu \mathrm{g} . \mathrm{L}^{-1}\right)$, mostly due to the high C. raciborskii density, reflects on low water transparency (Secchi depth $\sim 1.0 \mathrm{~m}$ ).

\footnotetext{
${ }^{1}$ Laboratório de Ecologia de Águas Continentais, Universidade Federal de Santa Catarina, 88040-900, Florianópolis, SC, Brazil

${ }^{2}$ Laboratório de Ecotoxicologia. Instituto Federal de Educação Ciência e Tecnologia de Santa Catarina, 88020-300, Florianópolis, SC, Brazil

* Corresponding author: denisetonetta@yahoo.com.br
} 
Cylindrospermopsis raciborskii is a filamentous Cyanobacteria, which has been recorded worldwide and can promote damages to water quality as a result of toxin production (Padisák 1997, and references on Tab.1). This species presents a great ecological success that is attributed to many factors, as shown in Tab. 1.

In Peri Lake, this species has been recorded since 1994 (Laudares-Silva 1999; Grellmann 2006) and since 2009 has accounted for about $90 \%$ of phytoplankton total density, showing dominance throughout most of the year (Tonetta et al. 2013; Silveira 2013). Although nutrient concentration has not shown significant changes since 1994, the phytoplankton density has increased considerably. In 1996 and 1997, C. raciborskii varied between 3 and $41 \times 10^{3}$ ind. $\mathrm{mL}^{-1}$ (Laudares-Silva 1999). During 2004-2005, the densities were 40 to $116 \times 10^{3}$ ind. $\mathrm{mL}^{-1}$ (Grellmann 2006); and in 2009-2011, the density varied from 23 to $220 \times 10^{3}$ ind. $\mathrm{mL}^{-1}$ (Tonetta et al. 2013).

In a recent review by Soares et al. (2013), the authors highlighted the occurrence of Cyanobacteria in Brazil, especially the genera Cylindrospermopsis Seenayya \& Subba-Raju, Dolichospermum (Ralfs ex Bornet \& Flahault) P.Wacklin, L.Hoffmann \& J.Komárek, and Microcystis Kützing ex Lemmermann, and the habitat preferences for these species. In this sense, Dolichospermum and Microcystis dominated mainly in warm-rainy periods, whereas Cylindrospermopsis was more common during colder-dry periods, in mixed systems, and with maximum $\mathrm{P}$ concentrations, as it is well known in the worldwide literature. It is well recognized that Cylindrospermopsis has been extending its distribution to colder regions (Vidal \& Kruk 2008; Sinha et al. 2012), although always in systems with high nutrients concentration. Here we focus on trying to understand the features leading to C. raciborskii dominance in an environment with low $\mathrm{P}$ concentration, light limitation, constantly mixed, and showing $C$. raciborskii dominance even at low temperatures (Hennemann \& Petrucio 2011; Tonetta et al. 2013).

Cyanobacteria can be dominant in low nutrient conditions due to the high affinity for $\mathrm{P}$, which allows them to outcompete other phytoplankton species (Carey et al. 2012; Rigosi et al. 2014). However, reports of Cyanobacteria dominance or persistence under low phosphorus conditions are absent to our knowledge. Some studies have cited the presence but not the dominance of $C$. raciborskii in poor nutrient lakes. In Gomes et al. (2013), it was not possible to identify if $C$. raciborskii was constant or sporadic in low P Brazilian systems (Duas Bocas - ES; Funil, Juturnaíba, Imboassica - RJ), because the dataset was constructed with the occurrence of C. raciborskii at least sporadically. A recent publication has shown the ability of $C$. raciborskii to dominate under very low (7:1) and very high (122:1) N:P ratios, but in experimental conditions (Chislock et al. 2014). Thus, to our knowledge, Peri Lake is the only low $\mathrm{P}$ environment in which this species is dominant for prolonged periods.
In an attempt to explain C. raciborskii dominance, Soares et al. (2013) did not raise two important features: competition and $\mathrm{P}$ storage, possibly because their research found this species in eutrophic waters. In this sense, the ability of C. raciborskii to tolerate wide variations in nutrient availability and fix atmospheric nitrogen is well documented (Isvánovics et al. 2000; Moisander et al. 2012), as well the high ammonium and nitrate uptake affinity (Présing et al. 1996). Literature review shows that $C$. raciborskii can present physiological trade-offs in abilities to acquire and utilize resources, especially the advantage over bacteria and/ or other phytoplankton to quickly assimilate $\mathrm{P}$ (Currie \& Kalf 1984; Prinsep et al. 2001; Marinho et al. 2013), being considered an opportunistic species in its P-storage capacity (Isvánovics et al. 2000). Due to this ecophysiology flexibility there is evidence that $C$. raciborskii from several parts of the world have different genotypes (Dyble et al. 2002; Fathalli et al. 2011) and ecotypes that are able to growth in lakes of different trophic status (Piccini et al. 2011).

The lower light requirements of $C$. raciborskii (Wu et al. 2009; Gomes et al. 2013) make possible for this species to survive under conditions that are limiting to other Cyanobacteria (Jensen et al. 1994; Padisák 1997; Briand et al. 2002; Posselt et al. 2009). In addition, this species can live in deep and turbid systems, excluding other phytoplankton (Scheffer et al. 1997; Marinho et al. 2013).

Many other important eco-physiological traits have been related to C. raciborskii success, such as toxin production, grazing resistance and allelopathic effects (Leonard \& Pearl 2005; Figueredo et al. 2007; Panosso \& Lürling 2010 and references on Tab.1). Allelopathy was suggested by Figueredo et al. (2007), according to which C. raciborskii exudates showed strong inhibitory effects on photosynthetic activity of several phytoplankton species. Bittencourt-Oliveira et al. (2012) showed that C. raciborskii exhibited considerable phenotype plasticity, changing the morphology of the trichomes during the development of the cultures. In Peri Lake, Komárková et al. (1999) found an extreme morphology of $C$. raciborskii filaments, possibly related to the deficient nutrient condition. These filaments, when isolated and cultivated in laboratory conditions, change their morphology (R Laudares-Silva, unpubl. res.). All these characteristics make C. raciborskii an unusually competitor which may be favoring and contributing to its dominance in Peri Lake. In this sense, the presence of $C$. raciborskii in this system could be related to the physiological flexibility and phenotypic plasticity of the species.

The findings in Peri Lake point out to many possible factors driving C. raciborskii dominance. Tonetta et al. (2013) found density changes driven by changes in water temperature and nutrient availability. Furthermore, the authors suggested that some filamentous species could co-exist with C. raciborskii (e.g. Limnothrix sp. Meffert, Planktolyngbya brevicellularis G.Cronberg \& Komárek, and P. limnetica (Lemmerm.) Komárk.-Legn. \& Cronberg), each 
Table 1. Features of $C$. raciborskii that corroborate its high ecological success.

\begin{tabular}{|c|c|}
\hline Features & Authors \\
\hline High affinity and P-storage ${ }^{\varepsilon}$ & Currie \& Kalf 1984, Isvánovics et al. 2000 \\
\hline Presence of heterocytes ${ }^{\sharp}$ & Padisák 1997, Moisander et al. 2012 \\
\hline Tolerance to low light ${ }^{\mathfrak{}}$ & Wu et al. 2009, Gomes et al. 2013 \\
\hline Production of toxins ${ }^{¥}$ & Othani et al. 1992, Hawkins et al. 1997, Lagos et al. 1999, Molica et al. 2002 \\
\hline Grazing resistance ${ }^{¥}$ & Leonard \& Pearl 2005, Soares et al. 2009, Panosso \& Lürling 2010, Hong et al. 2013 \\
\hline Allelopathic effects ${ }^{\varepsilon}$ & Figueredo et al. 2007 \\
\hline Phenotypic plasticity ${ }^{£}$ & Bonilla et al. 2011, Bittencourt-Oliveira et al. 2012 \\
\hline Tolerance to salinity ${ }^{\varepsilon}$ & Padisák 1997, Carneiro et al. 2013 \\
\hline Buoyancy regulation ${ }^{*}$ & Padisák 1997 \\
\hline Akinetes ${ }^{¥}$ & Moore et al. 2004 \\
\hline
\end{tabular}

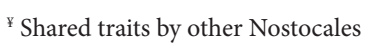

${ }^{E}$ Particular traits of Cylindrospermopsis raciborskii

of them having distinct niches or competing for the same resource (more details in Tonetta et al. 2013). On the other hand, the mixing in Peri Lake could act as a disturbance factor, which according to Baptista \& Nixdorf (2014), could explain the occurrence of steady states at low disturbance levels in Peri Lake and consequently the dominance of $C$. raciborskii. Recently, Fuentes \& Petrucio (2015) have suggested that physical conditions could directly influence phytoplankton growth; however, the authors did not present C. raciborskii data.

Finally, the literature review shows that the dominance of C. raciborskii around the world and in Brazilian ecosystems cannot be predicted from a single factor, especially when the factors are synergic. Thus, the comprehension of the characteristics that allow $C$. raciborskii to succeed in low $\mathrm{P}$ conditions is crucial for predicting future bloom-forming behavior in global changing scenarios, especially in the context of cyanotoxins and its allelopathic effects.

In this sense, nutrients itself do not explain the high densities of $C$. raciborskii, and physical conditions of the lake and species physiology should be considered as important factors driving the occurrence and dominance of this Cyanobacteria. Studies in Peri Lake have been shown that C. raciborskii can dominate even in low nutrient conditions and low light availability, what may have important consequences in management of eutrophic systems in which this is species is also dominant. More studies are necessary to better understand the factors that promote the dominance of this species, especially in low P systems.

\section{References}

Baptista MG, Nixdorf B. 2014. Low disturbances favor steady state: Case of cyanobacterial monodominance in a Brazilian coastal lagoon. Inland Waters 4: 243-254.

Bittencourt-Oliveira MC, Buch B, Hereman TC, Arruda-Neto JDT, Moura AN, Zocchi SS. 2012. Effects of light intensity and temperature on Cylindrospermopsis raciborskii (Cyanobacteria) with straight and coiled trichomes: growth rate and morphology. Brazilian Journal of Biology 72: 343-351.

Bonilla S, Aubriot L, Soares MCS, et al. 2011. What drives the distribution of the bloom-forming cyanobacteria Planktothrix agardhii and Cylindrospermopsis raciborskii? FEMS Microbiology Ecology 79: 594-607.

Briand J-F, Robillot C, Quiblier-Lloberas C, Humbert J-F, Coute A, Bernard C. 2002. Environmental context of Cylindrospermopsis raciborskii (Cyanobacteria) blooms in a shallow pond in France. Water Research 36: 3183-3192.

Carey CC, Ibelings BW, Hoffmann EP, Hamilton DP, Brookes JD. 2012. Eco-physiological adaptations that favor freshwater cyanobacteria in a changing climate. Water Research 46: 1394-1407.

Carneiro RL, Pacheco ABF, Azevedo SMFO. 2013. Growth and saxitoxin production by Cylindrospermopsis raciborskii (Cyanobacteria) correlate with water hardness. Marine Drugs 11: 2949-2963.

Chislock MF, Sharp KL, Wilson AE. 2014. Cylindrospermopsis raciborskii dominates under very low and high nitrogen-to-phosphorus ratios. Water Research 49: 207-214.

Currie DJ, Kalff J. 1984. A comparison of the abilities of freshwater algae and bacteria to acquire and retain phosphorus. Limnology and Oceanography 29: 298-310.

Dolman AM, Rucker J, Pick FR, et al. 2012. Cyanobacteria and cyanotoxins: the influence of nitrogen versus phosphorus. PLoS ONE 7: 38757.

Dyble J, Paerl HW, Neilan BA. 2002. Genetic characterization of Cylindrospermopsis raciborskii (Cyanobacteria) isolates from diverse geographic origins based on nifh and $c p c b a$-igs nucleotide sequence analysis. Applied and environmental Microbiology 68: 2567-2571.

Fathalli A, Jenhani ABR, Moreira C, et al. 2011. Genetic variability of the invasive cyanobacteria Cylindrospermopsis raciborskii from Bir M'cherga reservoir (Tunisia). Archives of Microbiology 193: 595-604.

Figueredo CC, Giani A, Bird DF. 2007. Does allelopathy contribute to Cylindrospermopsis raciborskii (Cyanobacteria) bloom occurrence and geographic expansion? Journal of Phycology 43: 256-265.

Fuentes EV, Petrucio MM. 2015. Water level decrease and increased water stability promotes phytoplankton growth in a mesotrophic subtropical lake. Marine and Freshwater Research http://dx.doi.org/10.1071/ MF14110.

Gomes AMA, Marinho MM, Azevedo SMFO. 2013. Which factors are related to the success of Cylindrospermopsis raciborskii in Brazilian Aquatic Systems? In: Ferrão-Filho AS. (ed.) Cyanobacteria: ecology, Toxicology and Management. New York, Nova Science Publishers Inc. p. 73-94.

Grellmann C. 2006. Aspectos da morfologia e da ecologia de Cylindrospermopsis raciborskii (Woloszynska) Seenayya et Subba Raju e da produção de cianotoxinas na Lagoa do Peri, Florianópolis, SC, Brasil. Msc Thesis, Universidade Federal de Santa Catarina, Brazil. 
Hawkins PR, Chandrasena NR, Jones GJ, Humpage AR, Falconer IR. 1997. Isolation and toxicity of Cylindrospermopsis raciborskii from an ornamental lake. Toxicon 35: 341-346.

Heisler J, Glibert PM, Burkholder JM, et al. 2008. Eutrophication and harmful algal blooms: a scientific consensus. Harmful Algae 8: 3-13.

Hennemann MC, Petrucio MM. 2011. Spatial and temporal dynamic of trophic relevant parameters in a subtropical coastal lagoon in Brazil. Environmental Monitoring and Assessment 181: 347-361.

Hong Y, Burford MA, Ralph PJ, Udy JW, Doblin MA. 2013. The cyanobacterium Cylindrospermopsis raciborskii is facilitated by copepod selective grazing. Harmful Algae 29: 14-21.

Isvánovics V, Shafik HM, Presing M, Juhos S. 2000. Growth and phosphate uptake kinetics of the cyanobacterium, Cylindrospermopsis raciborskii (Cyanophyceae) in through flow cultures. Freshwater Biology 43: 257-275.

Jensen P, Jeppesen E, Olrik K, Kristensen P. 1994. Impact of nutrients and physical factors on the shift from cyanobacterial to chlorophyte dominance in shallow Danish lakes. Canadian Journal of Fisheries and Aquatic Sciences 51: 1692-1699.

Komárková J, Laudares-Silva R, Senna PAC. 1999. Extreme morphology of Cylindrospermopsis raciborskii (Nostocales, Cyanobacteria) in the Lagoa do Peri, a freshwater coastal lagoon, Santa Catarina, Brazil. Algological Studies 94: 207-222.

Lagos N, Onodera H, Zagatto PA, Andrinolo D, Azevedo SMFO, Oshima Y. 1999. The first evidence of paralytic shelfish toxins in the freshwater cyanobacterium Cylindrospermopsis raciborskii, isolated from Brazil. Toxicon 37: 1359-1373.

Laudares-Silva R. 1999. Aspectos limnológicos, variabilidade espacial e temporal na estrutura da comunidade fitoplanctônica da Lagoa do Peri, Santa Catarina, Brasil. PhD Thesis, Universidade Federal de São Carlos, Brazil.

Leonard J, Pearl HW. 2005. Zooplankton community structure, microzooplankton grazing impact, and seston energy content in the St Johns river Florida as influenced by the toxic cyanobacterium Cylindrospermopsis raciborskii. Hydrobiologia 537: 89-97.

Marinho MM, Sousa MBG, Lurling M. 2013. Light and phosphate competition between Cylindrospermopsis raciborskii and Microcystis aeruginosa is strain dependent. Microbial Ecology 66: 479-488.

Moisander PH, Cheshire LA, Braddy J, et al. 2012. Facultative diazotrophy increases Cylindrospermopsis raciborskii competitiveness under fluctuating nitrogen availability. FEMS Microbiology Ecology 79: 800-811.

Molica RJR, Oliveira EJA, Carvalho PVVC, et al. 2002. Toxins in the freshwater cyanobacterium Cylindrospermospsis raciborskii (Cyanophyceae) isolated from Tabocas reservoir in Caruaru, Brazil, including demonstration of a new saxitoxin analogue. Phycology 41: 606-611.

Moore D, McGregor GB, Shaw G. 2004. Morphological changes during akinete germination in Cylindrospermopsis raciborskii (Nostocales, Cyanobacteria). Journal of Phycology 40: 1098-1105.

Ohtani I, Moore RE, Runnegar MTC. 1992. Cylindrospermopsin: A potent hepatotoxin from the blue-green alga Cylindrospermopsis raciborskii. Journal of the American Chemical Society 114: 7941-7942.

Padisák J. 1997. Cylindrospermopsis raciborskii (Woloszyska) Seenayya et SubbaRaju, an expanding, highly adaptive cyanobacterium: worldwide distribution and review of its ecology. Archives of Hydrobiology Supplement 107: 563-593.

Panosso R, Lürling M. 2010. Daphnia magna feeding on Cylindrospermopsis raciborskii: the role of food composition, filament length and body size. Journal of Plankton Research 32: 1393-1404.

Pearl HW, Huisman J. 2008. Blooms like it hot. Science 320: 57-58.

Piccini C, Aubriot L, Fabre A, et al. 2011. Genetic and eco-physiological differences of South American Cylindrospermopsis raciborskii isolates support the hypothesis of multiple ecotypes. Harmful Algae 10: 644-653.

Posselt AJ, Burford MA, Shawn G. 2009. Pulses of phosphate promote dominance of the toxic cyanophyte Cylindrospermopsis raciborskii in a subtropical water reservoir. Journal of Phycology 45: 540-546.

Présing M, Herodek S, Voros L, Kóbor I. 1996. Nitrogen fixation, ammonium and nitrate uptake during a bloom of Cylindrospermopsis raciborskii in Lake Balaton. Archiv fur Hydrobiologie 136: 553-562.

Prinsep MR, Caplan FR, Moore RE, Patterson GML, Honkanen RE, Boynton AL. 2001. Microcystin-LA from a blue-green alga belonging to the Stigonematales. Phytochemistry 31: 1247-1248.

Reynolds CS. 2006. The ecology of phytoplankton. Cambridge, Cambridge University Press.

Rigosi A, Carey CC, Ibelings BW, Brookes JD. 2014. The interaction between climate warming and eutrophication to promote cyanobacteria is dependent on trophic state and varies among taxa. Limnology and Oceanography 59: 99-114.

Scheffer M, Rinaldi S, Gragnani A, Mur LR, Nes EH. 1997. On the dominance of filamentous cyanobacteria in shallow, turbid lakes. Ecology 78: $272-282$

Silveira MH. 2013. Estrutura e dinâmica do fitoplâncton e fatores direcionadores da dominância anual de cianobactérias em uma lagoa rasa subtropical (lagoa do Peri, SC). Msc Thesis, Universidade Federal de Santa Catarina, Brazil.

Sinha R, Pearson LA, Davis TW, Burford MA, Orr PT, Neilan BA. 2012. Increased incidence of Cylindrospermopsis raciborskii in temperate zones: Is climate change responsible? Water Research 46: 1408-1419.

Soares MC, Lürling M, Panosso R, Huszar V. 2009. Effects of the cyanobacterium Cylindrospermopsis raciborskii on feeding and life-history characteristics of the grazer Daphnia magna. Ecotoxicology and Environmental Safety 72: 1183-1189.

Soares MC, Huszar VLM, Miranda MN, Mello MM, Roland F, Lürling M. 2013. Cyanobacterial dominance in Brazil: distribution and environmental preferences. Hydrobiologia 717: 1-12.

Tonetta D, Petrucio MM, Laudares-Silva R. 2013. Temporal variation in phytoplankton community in a freshwater coastal lake of southern Brazil. Acta Limnologica Brasiliensia 25: 99-110.

Vidal L, Kruk C. 2008. Cylindrospermopsis raciborskii (Cyanobacteria) extends its distribution to Latitude $34^{\circ} 53^{\prime} \mathrm{S}$ : taxonomical and ecological features in Uruguayan eutrophic lakes. Pan-American Journal of Aquatic Sciences 3: 142-151.

Wu Z, Shi J, Li R. 2009. Comparative studies on photosynthesis and phosphate metabolism of Cylindrospermopsis raciborskii with Microcystis aeruginosa and Aphanizomenon flos-aquae. Harmful Algae 8: 910-915. 